CESIS Electronic Working Paper Series

Paper No. 353

\title{
Is Export Diversification good for Profitability? First Evidence for Manufacturing Enterprises in Germany
}

Joachim Wagner

March, 2014 


\title{
Is Export Diversification good for Profitability? First Evidence for Manufacturing Enterprises in Germany *
}

\author{
Joachim Wagner \\ Leuphana University Lueneburg and CESIS, Stockholm
}

[This version: March 24, 2014]

\begin{abstract}
This paper uses a tailor-made newly available data set for enterprises from manufacturing industries in Germany to investigate for the first time the links between export diversification over destination countries and goods on the one hand and the profitability of the exporting firms on the other hand. We find that profits tend to be larger in firms with less diversified export sales over goods and in firms with more diversified export sales over destination countries.
\end{abstract}

Keywords: Exports; diversification; profitability; Germany JEL Classification: F14

\footnotetext{
All computations were done at the Research Data Centre of the Statistical Office of BerlinBrandenburg in Berlin. The firm-level data used are strictly confidential but not exclusive; see http://www.forschungsdatenzentrum.de/datenzugang.asp for information on how to access the data. To facilitate replications the Stata do-file used is available from the author on request.
}

Prof. Dr. Joachim Wagner

Leuphana University Lueneburg

Institute of Economics

PO Box 2440

D-21314 Lueneburg, Germany

e-mail: wagner@leuphana.de

www: http://www.leuphana.de/joachim-wagner.html 


\section{Motivation}

Over the past twenty years a huge literature emerged that uses micro-data at the firm level to investigate econometrically the links between different forms of international firm activities (exports, imports, offshoring, foreign direct investment) and various dimensions of firm performance (including firm size, productivity, wages, innovation and survival). ${ }^{1}$ One performance dimension that has been investigated only in a very small number of studies from this literature is profitability. This comes as a surprise because profit maximization can be regarded as a central aim of a firm. The number of studies on trade and profits, however, is still small and the number of countries covered (all of which are member states of the EU) is even smaller. Wagner (2012b) surveys the evidence for five countries from six studies. Results differ widely across the studies - from positive to no to negative profitability differences between exporters and non-exporters; from evidence for self-selection of more or less profitable firms into exporting to no evidence for self-selection at all; from no positive effects of exports on profits to positive effects.

A dimension of the export performance of firms that has to the best of my knowledge not been investigated at all empirically with a look at its link to firm profitability is the diversification of export activities of firms. It is now well known that not all exporting firm do export only one good to one country of destination - many firms diversify their exports by trading many different goods with customers that are located in many different destination countries. Wagner (2012c) documents that Germany, one of the leading actors on the world market for goods, is a case in point.

How is the extent of diversification of exports in product space and country space linked to firm profitability? Should a firm diversify their exports, i.e. should it

\footnotetext{
${ }^{1}$ For a recent survey of this literature see Wagner (2012a).
} 
export more than one good and spread export activities across markets when it goes for a better performance? In the literature, a related question has been discussed widely with regard to the link between firm profitability and diversification on the local or national market without viewing exports as another option of diversification. Braakmann and Wagner (2011, p. 326f.) summarize this discussion as follows.

According to the resource view (Montgomery 1994, p.167f.) firms that have an excess capacity in productive factors - for example, special knowledge the firm has accumulated through time, and that can be used in other markets without reducing the use in the market the firm is already active in - can reap economies of scope by expanding into different product markets. Alternatively, the firm may sell this specific asset to another firm active in this market. However, it is reasonable to expect that market failure does exist when it comes to trade in intangible assets like knowledge, and this is an incentive to internalize the use of the assets. Furthermore, productive factors of this type are often closely linked to persons who cannot simultaneously work for several firms producing different products. If a firm owns intangible assets of this type that make it successful in one market, and if these assets can be used in other markets, too, one would expect diversification into other product markets to be positive for firm performance. However, there are extra costs to be considered, too, because producing for a new market usually is connected to costs for developing and introducing the new product, including costs for market research and marketing.

A second line of reasoning points to the reduction of risk and uncertainty that can be reached by diversification across product markets (Lipczynski and Wilson 2001, p. 324f.). Demand shocks or new competitors may have a negative impact on sales and profits in a product market in an unpredictable manner. A single-product firm, therefore, is highly vulnerable to adverse shocks that hit their market. A multi- 
product firm can substantially reduce this vulnerability, especially if the risks on the various product markets are randomly distributed or negatively correlated (for a formal model see Hirsch and Lev 1971). Risk reduction will lead to more stable profits. More stable profits may be positively related to growth because they can secure the funds for investment at lower costs, and this may have a positive influence on the level of profits. Again, there are extra costs associated with the serving of different product markets that have to be considered, too.

Whether product diversification is good or bad for firm performance, and to which extent, therefore, is an empirical question. Results so far are mixed. Hall (1995, p. 26) summarizes the findings of a number of studies as follows: "The relationship between diversification and organisational performance has been the subject of numerous studies over the years ..., with results suggesting: negative relationships ..., positive relationships ..., and lack of relationship .... Regardless of how diversification is measured ..., the corporate diversification literature has failed to reach consensus about the relationship between firm diversification and performance." Similarly, Montgomery (1994, p. 172) argues that the literature surveyed by her "clearly shows that diversification is not a guaranteed route to success."

The theoretical arguments pro and contra diversification as a strategy for a firm to improve its profits discussed above hold for the diversification of exports, too. That said, the link between firm profitability on the one hand and export diversification in product space and country space on the other hand has not been investigated econometrically before. This paper intends to fill this gap. It uses a tailor-made newly available data set (described in detail in section 2) to investigate this link for enterprises from manufacturing industries in Germany, one of the leading actors on 
the world market for goods. To anticipate the most important finding, the paper demonstrates that profits tend to be larger in firms with less diversified export sales over goods and in firms with more diversified export sales over destination countries.

\section{Data and measurement issues}

The lack of empirical studies on the link between profitability and export diversification is due to the fact that until most recently suitable data at the level of the firm that could be used in an econometric investigation were not available. The empirical investigation here uses a tailor-mad data set that combines for the first time high quality firm-level data from three official sources.

The first source is the regular survey of establishments from manufacturing industries by the Statistical Offices of the German federal states. The survey covers all establishments from manufacturing industries that employ at least twenty persons in the local production unit or in the company that owns the unit. Participation of firms in the survey is mandated in official statistics (see Malchin and Voshage (2009) for details). For this study establishment data were aggregated to the enterprise level to match the unit of observation in the other data sources (described below). From this survey information is used on the number of employees in the firm and detailed industry affiliation.

The second source of data is the cost structure survey for enterprises in the manufacturing sector. This survey is carried out annually as a representative random sample survey. The sample is stratified according to the number of employees and the industries; all firms with 500 and more employees are covered by the cost structure survey (see Fritsch et al. 2004). This survey is the source for information on the profitability of a firm. 
Information on the goods traded internationally is available from the statistic on foreign trade (Außenhandelsstatistik). This statistic is based on two sources. One source is the reports by German firms on transactions with firms from countries that are members of the European Union (EU); these reports are used to compile the socalled Intrahandelsstatistik on intra-EU trade. The other source is transaction-level data collected by the customs on trade with countries outside the EU (the so-called Extrahandelsstatistik). ${ }^{2}$ Data in the statistic of foreign trade are transaction-level data, i.e. they relate to one transaction of a German firm with a firm located outside Germany at a time.

For the reporting years 2009 and 2010 these transaction-level data have been aggregated at the level of the exporting firm for the first time. Using the firms' registration number for turnover tax statistics these data were matched with the enterprise register system (Unternehmensregister-System) and with the enterprise level data from the two other sources discussed above. For each exporting or importing firm that reported either to the statistic on intra-EU trade, or to the statistic on trade with countries outside the $\mathrm{EU}$, we know from the data the value and the volume of exports and imports for the ten most important exported goods. This information is used to compute indicators for the diversification of exports.

With these data it is possible to investigate the relationship between export diversification and the profitability of the firm.

Diversification of exports is measured along two dimension, traded goods and partners in trade. Three indicators are used to measure the degree of diversification

\footnotetext{
${ }^{2}$ Note that firms with a value of exports to EU-countries that does not exceed 400,000 Euro in 2009 do not have to report to the statistic on intra-EU trade. For trade with firms from non-member countries all transactions that exceed 1,000 Euro are registered. For details see Statistisches Bundesamt, Qualitätsbericht Außenhandel, Januar 2011.
} 
of goods exported by a firm. The first indicator is the number of different goods exported by a firm, were a good refers to an eight-digit number from the official nomenclature for the statistics of foreign trade. A higher number of different exported goods indicates a higher degree of diversification. While this indicator treats each exported good alike, the second and the third indicator take care of the importance of the various products for the firm. The second indicator is defined as the share of the most important product of a firm in total exports of the firm, where importance is measured by the share of sales due to this good in total export sales. Analogously, the third indicator is defined as the share of the three most important products in total exports. A higher value of both indicators two and three points to a lower degree of export diversification of a firm.

The degree of diversification of countries exported to by a firm is measured in a similar way as the degree of diversification of goods exported. The first indicator is the number of different destination countries of exports by a firm. A higher number of different destination countries indicates a higher degree of diversification. While this indicator treats each destination country good alike, the second and the third indicator take care of the importance of the various trading partner countries for the firm. The second indicator is defined as the share of the most important destination country of a firm in total exports of that firm, where importance is measured by the share of sales to this country in total export sales. Analogously, the third indicator is defined as the share of the three most important destination countries in total exports. A higher value of both indicators two and three points to a lower degree of export diversification of a firm. ${ }^{3}$

\footnotetext{
${ }^{3}$ The data set used in this study has only information on the sales generated by the ten most important goods exported. Therefore, it is not possible to compute concentration measures that use
} 
The rate of profit of a firm is computed as a rate of return, defined as gross firm surplus (computed in line with the definition of the European Commission (1998) as gross value added at factor costs minus gross wages and salaries minus costs for social insurance paid by the firm) divided by total sales (net of VAT) minus net change of inventories: ${ }^{4}$

$$
\text { rate of profit }=\frac{\text { grossvalueadded }- \text { grosswages }- \text { cos ts for social insurance }}{\text { total sales }- \text { netchangeof inventories }}
$$

This profit measure is a measure for the price-cost margin which, under competitive conditions, should on average equal the required rental on assets employed per money unit of sales (see Schmalensee 1989, p. 960f.). Differences in profitability between firms, therefore, can follow from productivity differences, but also from different mark-ups of prices over costs and from differences in the capital intensity. ${ }^{5}$

Furthermore, the empirical model includes the number of employees (also included in squares to take care of non-linearity) to control for any relationship between firm size and firm profitability and a complete set of 4-digit level industry dummy variables to control for the role of industry-specific factors.

\footnotetext{
the information on the share of each product exported in total sales for firms with more than ten different exported goods like the Berry index (that is defined as 1 minus the sum of the squared shares of all products in total exports). The same holds for information on export sales to different countries.

${ }^{4}$ Note that the data set does not have any information on the capital stock, or the sum of assets or equity, of the firm, so that it is not possible to construct profit indicators based thereon like return on assets or return on equity.

${ }^{5}$ Given that the data set does not have information on the capital stock employed by the firms in the econometric investigations in the following sections differences in the capital intensity are controlled for by including detailed industry dummy variables at the 4-digit level.
} 
Given that the East German economy still differs in many respects from the West German economy, especially with regard to exporting (see Wagner (2008)), and that the number of exporting firms is small in East Germany this study looks at West German manufacturing enterprises only.

All computations are performed for two years, 2009 and 2010. In 2009, the value of German exports of goods declined by 18.4 percent compared to 2008 . This was followed by an increase in exports by 18.5 percent in 2010 (Statistisches Bundesamt 2012, p. 414). Therefore, a look at these two very different years can be considered as a robustness check to make sure that the results reported are not specific for a crises or recovery period.

\section{Empirical findings}

Descriptive statistics for profitability and the six measures for export diversification of the enterprises are reported in Table $1^{6}$. Note that firms are rather heterogeneous with regard to all characteristics looked at here. Both the rate of profitability and the extent of export diversification vary widely among the firms in the sample. Note further that profitability improved to a large degree from the export crisis in 2009 to the export boom in 2010.

[Table 1 near here]

How is the profitability of an exporting firm linked to the degree of export diversification? Are more diversified exporters more profitable? To investigate this

\footnotetext{
${ }^{6}$ Note that minimum and maximum values cannot be reported because they refer to a single enterprise and, therefore, are confidential.
} 
question empirical models are estimated with the rate of profit of a firm as the dependent variable and one of the six indicators of diversification of exports as the independent variable, controlling for firm size and a full set of detailed industry dummy variables measured at the 4-digit industry level. These estimated regression equations are not meant to be empirical models to explain profitability differences at the firm level; the data set at hand is not rich enough for such an exercise. The regression equations are just a vehicle to test for, and estimate the size of, diversification premia controlling for firm size and industry affiliation. This is a standard approach used in a huge number of empirical papers from the emerging literature on the links between international activities of heterogeneous firms and firm performance. $^{7}$

Results for the estimated profitability premia from the six different empirical models and the two years are reported in Table 2. While the number of goods exported per se is unrelated to the rate of profit earned by a firm according to the statistically insignificant regression coefficients from model 1 in both years there is a profitability premium for firms with a higher share of the most important good or the most important three goods in total exports (see model 2 and model 3, respectively). The estimated size of the premium is remarkably similar in the export crisis in 2009 and the export boom in 2010. Results differ when it comes to diversification of exports over space. In both years a higher number of destination countries of exports leads to a profitability premium (that is similar in both years), and at least in the boom year 2010 a higher concentration of exports on a small number of foreign markets goes hand in hand with lower profits. The big picture that emerges from the premia

\footnotetext{
${ }^{7}$ For recent surveys of this literature see Bernard et al. (2012), Melitz and Redding (2014) and Wagner (2012a).
} 
regressions reported in Table 2, therefore, can be summarized as follows: While it pays for the firms to concentrate exports on a smaller number of goods it pays to diversify in space and to export larger shares to a larger number of countries.

[Table 2 near here]

The discussion of the results from the empirical models so far only considered the statistical significance of the links between profitability and various indicators of export diversification. Evidently, statistically highly significant links can be irrelevant from an economic point of view if a ceteris paribus change of considerable size in export diversification goes hand in hand with tiny change in the (estimated) rate of profit only. To see whether the statistically significant links are relevant from an economic point of view, too, the estimated change in profits that is linked to a ceteris paribus increase by one standard deviation of the measure of export diversification is computed based on the estimated regression coefficients reported in Table 2.

To start with the diversification over goods exported an increase in the share of the most important product (or the three most important products) in total exports by one standard deviation leads to an estimated increase in the rate of profit by about 0.6 percentage points in both years. With a look at the average rate of profit of 4.8 percent in 2009 and 7.6 percent in 2010 this is a non-negligible effect from an economic point of view. Concentration of export sales on a small number of goods does matter for profitability.

Next, we look at export diversification over space. An increase of the number of destination countries by one standard deviation leads to an estimated increase in the rate of profit by 0.6 percentage points in 2009 and by 0.7 percentage points in 
2010. This is the same order of magnitude as in the case of an increase in the share of the most important product(s) by one standard deviation discussed above, and, therefore, it should be considered as non-negligible, too. However, a change by one standard deviation of the distribution of the number of destination countries means adding or dropping more than twenty countries (see Table 1), and this is really a large change. A decrease in the share of the most important country (or the three most important countries) in total exports has a statistically significant effect on profits in the boom year 2010 only. ${ }^{8}$ Here a change by one standard deviation is linked to an estimated increase in the rate of profit by 0.3 and 0.5 percentage points, respectively. These changes can be considered as non-negligible from an economic point of view. Therefore, we have some evidence that diversification of exports over space does matter for profitability.

\section{Discussion}

The discussion of theoretical considerations in section 1 pointed out that whether diversification of exports is good or bad for profitability is an empirical question. According to the empirical results presented in this study profitability in enterprises from German manufacturing industries is positively related to a higher degree of concentration of exports with regard to the share of the most important products in total sales on the one hand and to a higher degree of diversification of exports with

\footnotetext{
${ }^{8}$ Interestingly, this link between profitability and export diversification is different during the export crisis of 2009 and during the export boom in 2010. However, evidence for more years is needed before any relation between macroeconomic conditions and the profitability - export diversification link can be investigated in more detail.
} 
regard to the number and share of destination countries in total exports on the other hand.

This link between export diversification and profitability documents a correlation and should not be interpreted as a causal link from different dimensions of export diversification to profitability. With the cross-section data at hand it is impossible to investigate whether firms with a higher degree of diversification of exports with regard to the number and share of destination countries in total exports made higher profits on the national market already before they started to export, or whether a larger degree of export markets diversification lead to higher profits (or whether both is the case).

Another open question that has not been dealt with in this paper is the potential role played by unobserved firm characteristics like management quality for the profitability of firms. If these unobserved firm characteristics are correlated with the measures of export diversification that are included in the empirical model used to investigate the diversification premium, the estimated regression coefficients are biased and any conclusions based on the estimates have to take this potentially large bias into account. A standard solution to take at least those unobserved factors into account that do not change over the period under investigation is the addition of fixed firm effect to an empirical model that is estimated for panel data that cover all years from these period. This, however, is no feasible strategy here. As of today, the data used to construct the measures of export diversification are available for the years 2009 and 2010 only. Furthermore, these diversification indicators tend to be highly persistent at the level of the enterprise. Estimates from fixed effects panel data models that are based on the variation of variables over time inside a firm only, therefore, are no panacea here. 
That said, the reported statistically significant and economically non-negligible correlation between the profitability of a firm and the diversification over exported goods and destination countries of exports should be regarded as an interesting new finding that might motivate further investigations of the causes and consequences of differences in the diversification of exports in manufacturing firms.

\section{References}

Bernard, Andrew B., J. Bradford Jensen, Stephen J. Redding and Peter K. Schott (2012): The Empirics of Firm Heterogeneity and International Trade. Annual Review of Economics 4, 283-313.

Braakmann, Nils and Joachim Wagner (2011): Product Diversification and Profitability in German Manufacturing Firms. Journal of Economics and Statistics / Jahrbücher für Nationalökonomie und Statistik 231 (3), 326-335.

European Commission (1998): Commission Regulation (EC) No. 2700/98 concerning the definitions of characteristics for structural business statistics, Brussels. Official Journal of the European Communities L344, 18/12/1998, 49-80.

Fritsch, Michael, Bernd Görzig, Ottmar Hennchen and Andreas Stephan (2004): Cost Structure Surveys for Germany. Journal of Applied Social Science Studies 124 (4), 557-566.

Hall, Ernest H. (1995): Corporate Diversification and Performance: An Investigation of Causality. Australian Journal of Management 20 (1), 25-42.

Hirsch, Seev and Baruch Lev (1971): Sales Stabilization through Export Diversification. Review of Economics and Statistics 53 (3), 270-277.

Lipczynski, J. and J. Wilson (2001): Industrial Organisation. An Analysis of Competitive Markets. Harlow: Financial Times - Prentice Hall. 
Malchin, Anja and Ramona Voshage (2009): Official Firm Data for Germany. Schmollers Jahrbuch / Journal of Applied Social Science Studies 129 (3), 501513.

Melitz, Marc J. and Stephen Redding (2014): Heterogeneous Firms and Trade. Handbook of International Economics, Vol. 4, 1-54.

Montgomery, Cynthia A. (1994): Corporate Diversification. Journal of Economic Perspectives 8 (3), 163-178.

Schmalensee, Richard (1989): Inter-Industry Studies of Structure and Performance, in: Schmalensee, R. / Willig, R. D. (Ed.), Handbook of Industrial Organization, Volume II, Amsterdam etc.: North-Holland, 951-1009.

Statistisches Bundesamt (2012): Statistisches Jahrbuch 2012. Wiesbaden: Statistisches Bundesamt.

Wagner, Joachim (2008): A note why more West than East German firms export. International Economics and Economic Policy 5 (4), 363-370.

Wagner, Joachim (2012a): International trade and firm performance: a survey of empirical studies since 2006. Review of World Economics 148 (2), 235-267.

Wagner, Joachim (2012b): Exports, Imports and Profitability: First Evidence for Manufacturing Enterprises. Open Economies Review 23 (5), 747-765.

Wagner, Joachim (2012c): Trading many goods with many countries: Exporters and importers from German manufacturing industries. Review of Economics 63 (2), 170-186. 
Table 1: Descriptive statistics - Enterprise characteristics, West Germany

\begin{tabular}{llllll}
\hline $\begin{array}{l}\text { Entrerprise } \\
\text { characteristic }\end{array}$ & Mean & sd & p1 & p50 & p99 \\
\hline
\end{tabular}

2009

No. of enterprises: 5,993

Profitability (percent)

4.79

11.48

$-31.87$

5.29

29.48

Number of exported products

36.84

89.18

1

11

383

Share of most important

66.47

24.95

16.29

66.64

100

product in total exports (percent)

88.97

14.80

37.99

95.82

100

products in total exports (percent)

Number of destination countries

24.57

21.46

1

19

95

Share of most important country

in total exports (percent)

71.71

22.92

18.70

77.23

100

Share of three most important

89.37

12.53

46.02

94.05

100

countries in total exports (percent)

Number of employees

343.26

$2,683.88$

22

110.33

$2,699.3$

2010

No. of enterprises: 6,067

Profitability (percent)

Number of exported products

7.61

10.10

$-18.96$

7.41

31.04

Share of most important

39.92

88.97

1

12

408

product in total exports (percent)

Share of three most important

66.45

24.82

16.65

66.75

100

products in total exports (percent)

88.86

14.90

38.12

95.58

100

Number of destination countries

26.24

22.82

1

20

99

In exports

Share of most important country

41.62

24.74

10.13

34.33

100

Share of three most important

68.05

22.60

26.47

67.09

100

Number of employees

319.69

$2,314.10$

23

106.67

$2,626.3$

Note: For a detailed definition of the enterprise characteristics see text. p1, p50 and p99 refer to the $1^{\text {st }}, 50^{\text {th }}$ and $99^{\text {th }}$ percentile of the distribution of the characteristic (minima and maxima cannot be reported due to violation of privacy). 
Table 2: Profitability and diversification of exports: West Germany

\begin{tabular}{|c|c|c|c|c|c|c|c|}
\hline $\begin{array}{l}\text { Entrerprise } \\
\text { characteristic }\end{array}$ & & 1 & 2 & 3 & 4 & 5 & 6 \\
\hline \multicolumn{8}{|l|}{2009} \\
\hline $\begin{array}{l}\text { Number of exported } \\
\text { products }\end{array}$ & $\begin{array}{l}B \\
p\end{array}$ & $\begin{array}{l}-0.0013 \\
0.603\end{array}$ & & & & & \\
\hline $\begin{array}{l}\text { Share of most important } \\
\text { product in total exports }\end{array}$ & $\begin{array}{l}B \\
p\end{array}$ & & $\begin{array}{l}0.024 \\
0.000\end{array}$ & & & & \\
\hline $\begin{array}{l}\text { Share of } 3 \text { most important } \\
\text { products in total exports }\end{array}$ & $\begin{array}{l}B \\
p\end{array}$ & & & $\begin{array}{l}0.043 \\
0.000\end{array}$ & & & \\
\hline $\begin{array}{l}\text { Number of destination } \\
\text { contries in exports }\end{array}$ & $\begin{array}{l}B \\
p\end{array}$ & & & & $\begin{array}{l}0.028 \\
0.001\end{array}$ & & \\
\hline $\begin{array}{l}\text { Share of most important } \\
\text { country in total exports }\end{array}$ & $\begin{array}{l}B \\
p\end{array}$ & & & & & $\begin{array}{l}0.0012 \\
0.865\end{array}$ & \\
\hline $\begin{array}{l}\text { Share of } 3 \text { most import. } \\
\text { countries in total exports }\end{array}$ & $\begin{array}{l}B \\
p\end{array}$ & & & & & & $\begin{array}{c}-0.00030 \\
0.981\end{array}$ \\
\hline $\begin{array}{l}\text { Number of } \\
\text { employees }\end{array}$ & $\begin{array}{l}B \\
p\end{array}$ & $\begin{array}{l}-0.00027 \\
0.179\end{array}$ & $\begin{array}{l}-0.00021 \\
0.215\end{array}$ & $\begin{array}{l}-0.00015 \\
0.380\end{array}$ & $\begin{array}{l}-0.00061 \\
0.003\end{array}$ & $\begin{array}{l}-0.00034 \\
0.050\end{array}$ & $\begin{array}{l}-0.00034 \\
0.052\end{array}$ \\
\hline $\begin{array}{l}\text { Number of } \\
\text { employees (squared) }\end{array}$ & $\begin{array}{l}B \\
p\end{array}$ & $\begin{array}{l}2.06 \mathrm{e}-9 \\
0.232\end{array}$ & $\begin{array}{l}1.41 \mathrm{e}-9 \\
0.369\end{array}$ & $\begin{array}{l}9.99 \mathrm{e}-10 \\
0.535\end{array}$ & $\begin{array}{l}4.57 e-9 \\
0.019\end{array}$ & $\begin{array}{l}2.51 \mathrm{e}-9 \\
0.129\end{array}$ & $\begin{array}{l}2.46 e-9 \\
0.133\end{array}$ \\
\hline Constant & $\begin{array}{l}B \\
p\end{array}$ & $\begin{array}{l}4.91 \\
0.000\end{array}$ & $\begin{array}{l}3.23 \\
0.000\end{array}$ & $\begin{array}{l}0.99 \\
0.329\end{array}$ & $\begin{array}{l}4.27 \\
0,000\end{array}$ & $\begin{array}{l}4.80 \\
0.000\end{array}$ & $\begin{array}{l}4.91 \\
0.000\end{array}$ \\
\hline 4-digit industry controls & & yes & yes & yes & yes & yes & yes \\
\hline No. of enterprises & & 5,993 & 5,993 & 5,933 & 5,933 & 5,933 & 5,933 \\
\hline
\end{tabular}

2010

\begin{tabular}{|c|c|c|c|c|c|c|c|}
\hline $\begin{array}{l}\text { Number of exported } \\
\text { products }\end{array}$ & $\begin{array}{l}B \\
p\end{array}$ & $\begin{array}{l}-0.0030 \\
0.201\end{array}$ & & & & & \\
\hline $\begin{array}{l}\text { Share of most important } \\
\text { product in total exports }\end{array}$ & $\begin{array}{l}B \\
p\end{array}$ & & $\begin{array}{l}0.027 \\
0.000\end{array}$ & & & & \\
\hline $\begin{array}{l}\text { Share of } 3 \text { most important } \\
\text { products in total exports }\end{array}$ & $\begin{array}{l}B \\
p\end{array}$ & & & $\begin{array}{l}0.043 \\
0.000\end{array}$ & & & \\
\hline $\begin{array}{l}\text { Number of destination } \\
\text { contries in exports }\end{array}$ & $\begin{array}{l}B \\
p\end{array}$ & & & & $\begin{array}{l}0.031 \\
0.000\end{array}$ & & \\
\hline $\begin{array}{l}\text { Share of most important } \\
\text { country in total exports }\end{array}$ & $\begin{array}{l}B \\
p\end{array}$ & & & & & $\begin{array}{l}-0.012 \\
0.026\end{array}$ & \\
\hline $\begin{array}{l}\text { Share of } 3 \text { most import. } \\
\text { countries in total exports }\end{array}$ & $\begin{array}{l}B \\
p\end{array}$ & & & & & & $\begin{array}{r}-0.021 \\
0.001\end{array}$ \\
\hline $\begin{array}{l}\text { Number of } \\
\text { employees }\end{array}$ & $\begin{array}{l}B \\
p\end{array}$ & $\begin{array}{l}-0.00003 \\
0.900\end{array}$ & $\begin{array}{l}-0.00005 \\
0.763\end{array}$ & $\begin{array}{c}-0.00002 \\
0.929\end{array}$ & $\begin{array}{l}-0.00050 \\
0.011\end{array}$ & $\begin{array}{l}-0.00025 \\
0.157\end{array}$ & $\begin{array}{c}-0.00031 \\
0.088\end{array}$ \\
\hline
\end{tabular}




\begin{tabular}{|c|c|c|c|c|c|c|c|}
\hline $\begin{array}{l}\text { Number of } \\
\text { employees (squared) }\end{array}$ & $\begin{array}{l}B \\
p\end{array}$ & $\begin{array}{l}5.88 e-10 \\
0.720\end{array}$ & $\begin{array}{l}1.58 e-9 \\
0.739\end{array}$ & $\begin{array}{l}2.45 e-10 \\
0.880\end{array}$ & $\begin{array}{l}3.99 e-9 \\
0.020\end{array}$ & $\begin{array}{l}2.14 \mathrm{e}-9 \\
0.173\end{array}$ & $\begin{array}{l}2.61 e-9 \\
0.103\end{array}$ \\
\hline Constant & $\begin{array}{l}B \\
p\end{array}$ & $\begin{array}{l}7.74 \\
0.000\end{array}$ & $\begin{array}{l}5.83 \\
0.000\end{array}$ & $\begin{array}{l}3.81 \\
0.000\end{array}$ & $\begin{array}{l}6.94 \\
0,000\end{array}$ & $\begin{array}{l}8.19 \\
0.000\end{array}$ & $\begin{array}{l}9.12 \\
0.000\end{array}$ \\
\hline 4-digit industry controls & & yes & yes & yes & yes & yes & yes \\
\hline No. of enterprises & & 6,067 & 6,067 & 6,067 & 6,067 & 6,067 & 6,067 \\
\hline
\end{tabular}

Note: OLS regressions; dependent variable: Profitability (percent). $B$ is the estimated regression coefficient, $p$ is the prob-value (based on heteroscedasticity-consistent standard errors).For a detailed definition of the variables see text. 